\title{
Clinical implications of altered thyroid status in male testicular function
}

\author{
Implicações clínicas das alterações tireoidianas \\ na função gonadal masculina
}

Simone Magagnin Wajner' ${ }^{1}$ Márcia Santos Wagner' ${ }^{1}$ Ana Luiza Maia'

${ }^{1}$ Setor de Tireoide, Serviço de Endocrinologia, Hospital de Clínicas de Porto Alegre, Universidade Federal do Rio Grande do Sul (UFRGS), Porto Alegre, RS, Brasil
Correspondence to:

Ana Luiza Maia

Serviço de Endocrinologia do Hospital de Clínicas de

Porto Alegre

Rua Ramiro Barcelos, 2350

90035-003 - Porto Alegre, RS, Brasil

almaia@ufrgs.br

Received on Sept/30/2009

Accepted on Oct/16/2009

\begin{abstract}
Thyroid hormones are involved in the development and maintenance of virtually all tissues. Although for many years the testis was thought to be a thyroid-hormone unresponsive organ, studies of the last decades have demonstrated that thyroid dysfunction is associated not only with abnormalities in morphology and function of testes, but also with decreased fertility and alterations of sexual activity in men. Nowadays, the participation of triiodothyronine (T3) in the control of Sertoli and Leydig cell proliferation, testicular maturation, and steroidogenesis is widely accepted, as well as the presence of thyroid hormone transporters and receptors in testicular cells throughout the development process and in adulthood. But even with data suggesting that $\mathrm{T} 3$ may act directly on these cells to bring about its effects, there is still controversy regarding the impact of thyroid diseases on human spermatogenesis and fertility, which can be in part due to the lack of well-controlled clinical studies. The current review aims at presenting an updated picture of recent clinical data about the role of thyroid hormones in male gonadal function. Arq Bras Endocrinol Metab. 2009;53(8):976-82

Keywords

Testis; thyroid hormones; spermatogenesis; reproduction; fertility

\section{RESUMO}

Os hormônios da tireoide estão envolvidos virtualmente no desenvolvimento e na manutenção de todos os tecidos. As gônadas masculinas foram, por décadas, consideradas insensíveis aos hormônios tireoidianos. No entanto, estudos mais recentes têm demonstrado que disfunções tireoidianas estão associadas não somente a anormalidades na morfologia e na função dos testículos, mas também à diminuição da fertilidade e alterações na atividade sexual masculina. Atualmente, o papel da triiodotironina (T3) no controle da proliferação das células de Sertoli e Leydig, maturação testicular e esteroidogênese é amplamente aceito, bem como a presença de transportadores e receptores para o hormônio tireoidiano nos testículos durante o período de desenvolvimento e a idade adulta. No entanto, apesar dos dados que indicam que oT3 atua diretamente nos testículos humanos, persistem controvérsias em relação ao impacto das doenças tireoidianas sobre a espermatogênese e a fertilidade, o que pode ser em parte devido à escassez de estudos clínicos nessa área. Essa revisão tem por objetivo apresentar um panorama de dados clínicos atualizados sobre o papel dos hormônios tireoidianos na função gonadal masculina. Ara Bras Endocrinol Metab. 2009;53(8):976-82

Descritores

Testículo; hormônios tireoidianos; espermatogênese; reprodução; fertilidade
\end{abstract}

\section{INTRODUCTION}

I n mammals, altered thyroid status is known to adversely affect many organs and tissues. Nevertheless, for many years, the impact of thyroid disorders on male reproduction remained controversial. Early studies in the 1950's demonstrated that testes were essentially in- dependent of thyroid hormone effects $(1,2)$. For this reason, the potential of thyroid hormone in the modulation of male reproductive function was not determined.

However, in the past two decades, clinical studies have demonstrated that thyroid hormone plays an important role in testicular development and function. 
It is now established that $\mathrm{T} 3$ regulates the maturation and growth of testis, controlling Sertoli cell and Leydig cell proliferation and differentiation during testicular development in rats and other mammal species $(3,4)$. The efficiency of spermatogenesis, reflected by daily sperm production in adulthood, correlates to the total number of functional Sertoli cells established during prepubertal life (5). Furthermore, changes in thyroid hormone levels during early testis development have been shown to affect testicular maturation and reproduction later in life (6). These data, in conjunction to the findings that thyroid hormone receptors are present in human and rat testes from neonatal to adult life $(7,8)$, confirm that thyroid hormone plays a key role in testicular development. The presence of iodothyronine deiodinases, enzymes that modulate the concentration, and thus the action of thyroid hormones in different tissues, were also recently identified in the rodent testis from fetal to adult life (9-11). Clinical literature indicates that most patients with thyroid hormone disorders experience some kind of sexual dysfunction, which improves or normalizes when patients become euthyroid $(6,12,13)$. Hence, although thyroid hormone was not historically viewed as a major regulator of the male gonad, it is clear now that it has critical effects on the testis, especially during development period (14). This review intends to present an updated view of clinical studies regarding the effects of thyroid hormones on testicular function.

\section{THYROID HORMONES}

The thyroid hormones, thyroxin $\left(3,5,3^{\prime}, 5^{\prime}\right.$ ' L-tetraiodothyronine or T4) and the more potent triiodothyronine (3,5,3'-L-triiodothyronine or T3) are synthesized in the thyroid gland. Most of the hormone released is in the form of T4, as total serum T4 is 40 -fold higher than serum T3. The main pathway for the production of the bioactive form, T3, is via outer ring deiodination of the prohormone $\mathrm{T} 4$ by iodothyronine deiodinases (15). This activation reaction is catalyzed by types 1 and 2 deiodinases (D1 and D2) in peripheral tissues. Both T4 and T3 may also be inactivated by inner ring deiodination to 3,3',5-triiodothyronine (rT3) and 3,3'-diiodothyronine (T2) predominantly by type 3 deiodinase (D3), and to a lesser extent by Dl (16). Deiodination is the most important pathway of thyroid hormone metabolism not only in quantitative terms, but also because it accounts for most of the circulating T3 $(\sim 80 \%)$ in humans (17).
The serum concentrations of thyroid hormones are regulated by a negative feedback system that involves the hypothalamus, pituitary and thyroid gland (H-P$\mathrm{T}$ axis). Both the hypothalamic thyrotrophin-releasing hormone (TRH) and pituitary thyroid-stimulating hormone (TSH) secretions are negatively regulated by circulating thyroid hormones (18). The majority of thyroid gland-released hormones circulate in blood in order to carry proteins such as thyroxin binding globulin (TBG), albumin, and thyroid binding prealbumin. Only $0.03 \%$ of total serum T4 and approximately $0.3 \%$ of total serum T3 circulate as free (unbound) hormones.

Although thyroid hormones may exert their effects on a number of intracellular loci (16), their actions on target tissues are predominantly mediated by specific nuclear receptors (TRs) able to bind to regulatory regions of target genes modifying their expression (19). Two separate genes, TRa and TRb, encode thyroid hormone receptors (TRs). Similarly to other nuclear receptors, TR consists of a DNA-binding domain, ligand-binding domain and amino-terminal transactivation domain. The remaining non-hormone binding TR isoforms lack portions of the DNA-binding and/ or ligand-binding domains, and their functions are still unclear (20). In the nucleus, TRs recognize and bind to specific DNA sequences termed thyroid hormone response elements (TREs), located in the promoter region of target genes, and activate or repress transcription in response to $\mathrm{T} 3$ binding (Figure 1 ).

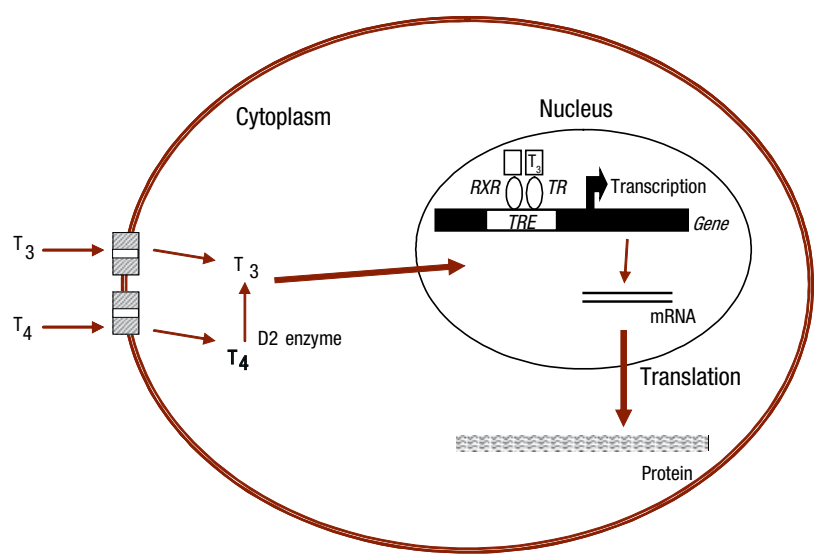

Figure 1. Schematic diagram depicting the thyroid hormone (T3) receptor (TR) mediated actions. (A) After the cellular uptake of thyroid hormones through transmembrane transporters, the precursor T4 is mainly converted into T3 by type 2 deiodinase (D2) located on the endoplasmic reticulum. In the nucleus, T3 binding to thyroid receptor (RXR-TR heterodimer) leads to dissociation of corepressors and binding of coactivators that allow the transcriptional machinery assembly and induction of transcription. 
In order to interact with specific nuclear receptors and generate a biological response, thyroid hormones have to cross cell membranes. It was originally believed that thyroid hormones, due to their lipophilic nature, enter target cells by passive diffusion. Currently, however, there is growing evidence indicating that $\mathrm{T} 4$ and $\mathrm{T} 3$ cross the plasma membrane by carrier mediated mechanisms $(20,21)$. Several membrane transporter families have been identified, however only monocarboxylate transporter (MCT) 8, MCT 10 and organic anion-transporting polypeptides (OATPs) demonstrate a high degree of specificity towards thyroid hormone (22). The OATPs form a novel family of transporter proteins that have been detected in several tissues, including testis, in rodents and humans (22-28).

\section{THYROID HORMONE AND TESTICULAR FUNCTION}

The testes are mainly comprised of tightly coiled seminiferous tubules, which are supported by loose interstitial connective tissue in which the steroidogenic Leydig cells are located (29). Inside the basement membrane of the seminiferous tubules, there is a columnar epithelium composed of germ cells and somatic Sertoli cells. It is well established that the number of Sertoli cells presented at puberty is closely correlated with both adult testicular size and sperm output, which is crucial for future male fertility (5). Although several factors are presumed to play a role in proliferation and maturation of Sertoli cells $(29,30)$, T3 is likely to represent a major hormonal signal to Sertoli cell proliferation during testicular development, and ultimately affecting the establishment of the adult Sertoli cell population.

Testes perform two major functions: production of gametes (spermatozoa) and androgen synthesis. The anterior pituitary participates in the control of both of these functions through its secretion of gonadotropins, with follicle stimulating hormone (FSH) acting directly on Sertoli cells and luteinizing hormone (LH) on interstitial Leydig cells (28). Testosterone, the main androgen produced by the latter cells in response to $\mathrm{LH}$, diffuses into the seminiferous tubules, where it is essential for spermatogenesis. Both testosterone and FSH are required for initiation and maintenance of spermatogenesis.

Thyroid hormones are also known to affect Leydig cells proliferation and function (4). Several studies have shown that altered thyroid status has remarkable effects on Leydig cell differentiation in experimental animals
$(4,30)$. Likewise, evidence of direct actions of thyroid hormones on Leydig cell steroidogenesis has been demonstrated in different studies $(31,32)$.

\section{Thyroid hormone disorders and androgenic hormones}

Although gonadotropins are the major regulators of testicular function, there is controversial with regard to the relationship between hypo- and hyperthyroidism and luteinising hormone $(\mathrm{LH})$ and follicle-stimulating hormone (FSH) levels in men. Prepubertal males affected by primary hypothyroidism have been reported with normal $(33,34)$ or, more frequently, elevated FSH and $\mathrm{LH}$ (33-37) and total serum testosterone in the prepubertal range $(33,36-41)$. The variations in the levels of LH and FSH have been reported in different studies on adult hypothyroid patients and results are somehow conflicting. Wortsman and cols. (42) investigated eight adult hypothyroid male patients aged 37 to 77 years. All patients had evidence of hypogonadism; five were hypergonadotropic, and the remaining three, hypogonadotropic. Other authors describe elevated (43) or even normal gonadotropin levels in these patients $(12,44)$. Basal serum gonadotrophin concentrations are usually normal in hyperthyroid males. $\mathrm{LH}$ and FSH response to exogenous GnRH seems to be significantly greater in thyrotoxic patients in comparison to patients who were rendered euthyroid $(44,45)$. It has been suggested that the LH elevation could be secondary to changes in sex steroid binding and peripheral metabolism, alterations in the hypothalamic-pituitary feedback, or due to the direct effect of thyroid hormones per se at this level (45). All these changes are fully reversible with restoration of the euthyroid state, and require no other specific treatment.

Several studies have shown a drop in the circulating level of testosterone in overt and subclinical hypothyroidism (12,40-44), whereas other studies (46), measuring free testosterone, did not find any change in its level in hypothyroid patients. Jaya Kumar and cols. (43) studied endocrine function of eight males with primary hypothyroidism during the hypothyroid phase and after achieving euthyroidism with T4 replacement levothyroxine therapy, and showed a subnormal testosterone response to hCG leading to reduced steroidogenesis, probably resulting from a testicular lesion induced by hypothyroidism. In contrast, Velazquez and Arata (47) observed normal testicular response of hCG in hypothyroid males. In rare cases of severe prolonged primary hypothyroi- 
dism, pituitary hyperplasia may occur causing multiple pituitary hormone deficiencies, including gonadotropin and corticotropin deficiencies (45). Low T3, high TSH and hyperprolactinemia caused by hypothyroidism could directly act on the Leydig cells in suppressing steroidogenesis $(42,43,46)$. All the above changes are fully reversible with restoration of euthyroid state (12). Hypothyroidism is also associated with a decreased serum total testosterone, dehydroepiandrosterone (DHEA), DHEA-sulfate and pregnenolone sulfate (12).

An increase in SHBG is a consistent feature associated with thyrotoxicosis, and leads to an increase in circulating levels of total T4 and reduction in the metabolic clearance rate of testosterone. However, the plasma level of free testosterone is usually maintained within the normal range, which is in keeping with the lack of clinical consequences of the noticeably elevated levels of total testosterone found in thyrotoxicosis (12). Peripheral conversion of androgen to estrogen is enhanced in thyrotoxicosis, probably due to changes in peripheral blood flow (47) rather than a direct effect of thyroid hormones on the aromatase complex. An increase in the production rate of estrogens is also observed in some men with thyrotoxicosis, although it is unclear whether this is due to increased production of adrenal androgen precursors (specifically $\Delta 4 \mathrm{~A}$ ) or to other mechanisms (48). Furthermore, serum progesterone was reported to be higher in hyperthyroid than in euthyroid males (49), while mean basal testosterone bioactivity was lower in patients as compared to controls (50). Thyrotoxic males often present clinical features compatible with exposure to increased estrogen bioactivity (gynecomastia, spider angiomas, and a decrease in libido) (5l). Whether this results from alterations in estrogen metabolism is a direct effect of hyperthyroxinemia is unknown.

\section{Thyroid hormone disorders and male reproduction}

Thyroid failure in the pre-pubertal period is associated with testicular enlargement as well as alterations in sexual hormones $(6,40)$. Hypothyroidism initiated in infancy may occur in association with macroorchidism without virilization, although the pathogenesis remains uncertain (6). The longer the hypothyroidism persists, the greater is the degree of damage to the testes $(6,52)$. When adequately treated with thyroid hormone, however, boys with congenital hypothyroidism progress through puberty normally and at the appropriate time (53-55).

Morphological changes may be observed in pubertal and adult men testes with chronic untreated hypothyroidism, although the results are conflicting. Griboff (56), investigated five hypothyroid patients and all demonstrated normal sperm counts, whereas other authors $(4,34,37,57)$ found morphological and spermatogenic alterations in testicular biopsies of prepubertal and adult hypothyroid patients. Hypothyroid prepubertal testis may present a preponderance of tubular compartment with early onset of spermatogenesis and no increase in the number of Leydig cells. Adult testis, however, may present fibrosis and hyalinization of tubular walls, fibroblastic proliferation, peritubular and interstitial fibrosis with sparse Leydig cells, as well as reduction of tubular diameter, interstitial edema and tubular basal membrane stickiness.

The potential role of thyroid hormone on mammalian spermatogenesis has been addressed by several studies (58). Corrales Hernandez and cols. (59) studied spermatogesis in ten treated hypothyroid patients. Changes in seminal and sperm profile after discontinuation of hormone replacement were not marked, although some decrement in motility was reported. Apparently, post-pubertal hypothyroidism does not cause severe seminal alterations. Another study designed to investigate the correlation of thyroid dysfunction and semen parameters in infertile men, however, analyzed 305 patients and did not find any correlation between thyroid dysfunction and semen parameters, but between elevated thyroid peroxidase antibody (TPO-Ab) and panthozoospermia and asthenozoospermia (60). These results, conversely, were not confirmed in a recent cohort of subfertile men (61). Recently, Meeker and cols. (62) found a positive association between free T4 and sperm concentration in a group of 388 men with mean age of $36 \pm 5.4$ years.

The effects of hyperthyroidism on male fertility were the topic of some studies. Early clinical observations have described oligospermia and loss of spermatozoa mobility in hyperthyroid men (63). The same findings were observed by Kidd and cols. with hyperthyroid patients and low total sperm counts (64). In the early 1990's, Hudson and Edwards (65) assessed testicular function in men with Graves's diseases and found that the percentage of forward progressive motility was significantly lower than control values. Seminal abnormalities were corrected when patients became euthyroid. Another study that evaluated the effects of Grave's disease on male reproduction showed that thyrotoxic male presented several changes on semen parameters, such as: asthenospermia, hypospermia, oligospermia, 
necrospermia and teratospermia, as well as complaints of impaired sexual function (49). A normalization of $85 \%$ of seminal alterations was observed when euthyroidism were reached. A recent controlled prospective study (66) showed that $50 \%$ of the 23 thyrotoxic males studied presented sexual dysfunction associated with decreased libido, which improved after treatment. These patients also showed lower sperm densities and motility, whereas no differences were found on sperm morphology. Again, following treatment of thyrotoxicosis, sperm density and motility improved, but sperm morphology did not change.

Erectile dysfunction and loss of libido or impotence are not uncommon in males with thyroid dysfunctions $(13,67)$. Carani and cols., conducting a clinical trial that evaluated 34 patients with hyperthyroidism and 14 with hypothyroidism, both initiated in adulthood, demonstrated that $12,8 \%$ of these men showed some degree of sexual function deterioration (14). The most common symptom in hyperthyroidism were precocious ejaculation, while hypothyroid patients referred a greater number of complaints such as erectile dysfunction, ejaculation delay, loss of libido and impotence. This study showed that most patients with thyroid hormone disorders experience some sexual dysfunctions that may be reversed with the normalization of thyroid hormone levels (14).

Erectile dysfunction were found in about $80 \%$ of patients with hyper- or hypothyroidism in a controlled study that investigated the impact of thyroid hormone alterations on male sexual health (67). After treatment, the proportion of erectile complaints were the same in both patients and control groups. Thyroid hormone alterations on male reproductive function are summarized on table 1 .

\section{CONCLUSION}

In the past decades, it has become clear that thyroid hormone plays an important role in Sertoli and Leydig cell proliferation and function, also influencing spermatogenesis, sperm motility and ultimately fertility. Disturbance of the normal euthyroid state affects the morphological and functional development of the testis. Thyroid hormone is also likely to contribute to normal spermatogenesis and metabolic processes in the adult testis, but these aspects are not completely understood at the present. Nevertheless, despite the gaps in our knowledge, the data herein reviewed may provide considerable evidence to conclude that thyroid hormone plays an important role in the human testicular development and function.

Grant support: Coordenação de Aperfeiçoamento de Pessoal de Nível Superior (Capes), Conselho Nacional de Desenvolvimento Científico e Tecnológico (CNPq), Fundação de Apoio à Pesquisa do Rio Grande do Sul (FAPERGS), Brazil.

Disclosure: no potential conflict of interest relevant to this article was reported.

\begin{tabular}{lccc}
\hline \multicolumn{1}{l}{ Table 1. Effects of hypo and hyperthyroidism on male gonadal function } & & \\
\hline & Hypothyroidism & Hyperthyroidism & Reference \\
\hline Prepubertal testicular volume and function & $\uparrow$ & $\downarrow$ & 6 \\
& Early onset of spermatogenesis & $\downarrow, 34$ \\
Sperm counting & Normal or $\downarrow$ & $\downarrow$ & $48,52,57-59$ \\
Sperm motility & $\downarrow$ & Impaired; precocious ejaculation & $54,58-61$ \\
Sexual function & Impaired & $\downarrow$ & $13,48,61,62$ \\
Erectile function & $\downarrow$ & $13,62,63$ \\
\hline
\end{tabular}

\section{REFERENCES}

1. Barker SB, Klitgaard HM. Metabolism of tissues excised from thyroxine-injected rats. Am J Physiol. 1952;170(1):81-6.

2. Oppenheimer JH, Schwartz HL, Surks MI. Tissue differences in the concentration of triiodothyronine nuclear binding sites in the rat: liver, kidney, pituitary, heart, brain, spleen, and testis. Endocrinol. 1974;95:897-903.

3. Holsberger DR, Kiesewetter SE, Cooke PS. Regulation of neonatal Sertoli cell development by thyroid hormone receptor alpha1. Biol Reprod. 2005;73(3):396-403.
4. Mendis-Handagama SM, Siril Ariyaratne HB. Leydig cells, thyroid hormones and steroidogenesis. Ind J Experim Biol. 2005;43:939-62.

5. Orth JM, Gunsalus GL, Lamperti AA. Evidence from Sertoli celldepleted rats indicates that spermatid number in adults depends on numbers of Sertoli cells produced during perinatal development. Endocrinol. 1988;122:787-94.

6. Jannini EA, Ulisse S, D'Armiento M. Thyroid hormone and male gonadal function. Endoc Rev. 1995;16(4):443-59.

7. Buzzard JJ, Morrison JR, O’Bryan MK, Song Q, Wreford NG. Developmental expression of thyroid hormone receptors in the rat testis. Biol Reprod. 2000;62(3):664-9. 
8. Jannini EA, Crescenzi A, Rucci N, Screponi E, Carosa E, de Matteis $A$, et al. Ontogenetic pattern of thyroid hormone receptor expression in the human testis. J Clin Endocrinol Metab. 2000;85(9):3453-7.

9. Bates JM, St Germain DL, Galton VA. Expression profiles of the three iodothyronine deiodinases, D1, D2, and D3, in the developing rat. Endocrinol. 1999;140:844-51.

10. Wagner MS, Morimoto R, Dora JM, Benneman A, Pavan R, Maia AL. Hypothyroidism induces type 2 iodothyronine deiodinase expression in mouse heart and testis. $\mathrm{J}$ Mol Endocrinol. 2003;31(3):541-50.

11. Wajner SM, dos Santos Wagner M, Melo RC, Parreira GG, Chiarini-Garcia $\mathrm{H}$, Bianco AC, et al. Type 2 iodothyronine deiodinase is highly expressed in germ cells of adult rat testis. J Endocrinol. 2007;194(1):47-54.

12. Krassas GE, Pontikides N. Male reproductive function in relation with thyroid alterations. Best Pract Res - Clin Endocrinol Metab. 2004;18(2):183-95.

13. Wagner MS, Wajner SM, Maia AL. The role of thyroid hormone in testicular development and function. J Endocrinol. 2008;199(3):351-65.

14. Carani C, Isidori AM, Granata A, Carosa E, Maggi M, Lenzi A, et al. Multicenter study on the prevalence of sexual symptoms in male hypo- and hyperthyroid patients. J Clin Endocrinol Metab. 2005;90(12):6472-9.

15. Kuiper GG, Kester MH, Peeters RT, Visser TJ. Biochemical mechanisms of thyroid hormone deiodination. Thyroid. 2005;15(8): 787-98.

16. Bianco AC, Maia AL, da Silva WS, Christoffolete MA. Adaptive activation of thyroid hormone and energy expenditure. Biosci Rep. 2005;25(3-4):191-208.

17. Maia AL, Kim BW, Huang SA, Harney JW, Larsen PR. Type 2 iodothyronine deiodinase is the major source of plasma T3 in euthyroid humans. J Clin Invest. 2005;115(9):2524-33.

18. Shupnik MA, Ridgway EC, Chin WW. Molecular biology of thyrotropin. Endoc Rev. 1989;10(4):459-75.

19. Shibusawa N, Hashimoto $K$, Nikrodhanond AA, Liberman MC, Applebury ML, Liao $\mathrm{XH}$, et al. Thyroid hormone action in the absence of thyroid hormone receptor DNA-binding in vivo. J Clin Invest. 2003;112(4):588-97.

20. Yen PM, Ando S, Feng X, LiuY, Maruvada P, Xia X. Thyroid hormone action at the cellular, genomic and target gene levels. Mol Cel Endocrinol. 2006;246(1-2):121-7.

21. O'Shea PJ, Williams GR. Insight into the physiological actions of thyroid hormone receptors from genetically modified mice. J Endocrinol. 2002;175(3):553-70.

22. Hennemann G, Docter R, Friesema EC, de Jong M, Krenning EP, Visser TJ. Plasma membrane transport of thyroid hormones and its role in thyroid hormone metabolism and bioavailability. Endoc Rev. 2001;22(4):451-76.

23. Neves FA, Cavalieri RR, Simeoni LA, Gardner DG, Baxter JD, Scharschmidt BF, et al. Thyroid hormone export varies among primary cells and appears to differ from hormone uptake. Endocrinol. 2002;143:476-83.

24. Visser WE, Friesema EC, Jansen J, Visser TJ. Thyroid hormone transport in and out of cells. Trends Endocrinol Metab. 2008;19:50-6.

25. Suzuki T, OnogawaT, Asano N, Mizutamari H, Mikkaichi T, Tanemoto $\mathrm{M}$, et al. Identification and characterization of novel rat and human gonad-specific organic anion transporters. Mol Endocrinol. 2003;17(7):1203-15.

26. Hagenbuch B, Meier PJ. Organic anion transporting polypeptides of the OATP/ SLC21 family: phylogenetic classification as OATP/ SLCO superfamily, new nomenclature and molecular/functional properties. P Arch: Eur J Physiol. 2004;447:653-65.
27. Hagenbuch B. Cellular entry of thyroid hormones by organic anion transporting polypeptides. Best Pract Res - Clin Endocrinol Metab. 2007;21:209-21.

28. Westholm DE, Rumbley JN, Salo DR, RichT, Anderson GW. Organic anion-transporting polypeptides at the blood-brain and bloodcerebrospinal fluid barriers. CurTop Devel Biol. 2008;80:135-70.

29. Griffin JE, Wilson JD. Disorders of the testes and the male reproductive tract. In: Larsen PR, Kronenberg HM, Melmed S, Polonsky KS, editors. Williams Textbook of Endocrinology. New York: Saunders; 2002. p. 709-769

30. Sharpe RM, McKinnell C, Kivlin C, Fisher JS. Proliferation and functional maturation of Sertoli cells, and their relevance to disorders of testis function in adulthood. Reprod. 2003;125:769-84.

31. Mackay S, Smith RA. Effects of growth factors on testicular morphogenesis. Intern Rev Cytol. 2007;260:113-73.

32. Maran RR. Thyroid hormones: their role in testicular steroidogenesis. Arch Androl. 2003;49(5):375-88.

33. Jana NR, Bhattacharya S. Binding of thyroid hormone to the goat testicular Leydig cell induces the generation of a proteinaceous factor which stimulates androgen release. J Endocrinol. 1994;143(3):549-56.

34. Manna PR, Tena-Sempere M, Huhtaniemi IT. Molecular mechanisms of thyroid hormone-stimulated steroidogenesis in mouse leydig tumor cells. Involvement of the steroidogenic acute regulatory (StAR) protein. J Biol Chem. 1999;274:5909-18.

35. Kugler JA, Huseman CA. Primary hypothyroidism of childhood: evaluation of the hypothalamic-pituitary gonadal axis before and during L-thyroxine replacement. Clin Endocrinol. 1983;19:213-22.

36. Buchanan CR, Stanhope R, Adlard P, Jones J, Grant DB, Preece MA. Gonadotrophin, growth hormone and prolactin secretion in children with primary hypothyroidism. Clin Endocrinol. 1988;29:427-36

37. Laron Z, Karp M, Dolberg L. Juvenile hypothyroidism with testicular enlargement. ACTA Paed Scand. 1970;59:317-22.

38. Hopwood NJ, Lockhart LH, Bryan GT. Acquired hypothyroidism with muscular hypertrophy and precocious testicular enlargement. J Ped. 1974;85:233-6.

39. Castro-Magana M, Angulo M, Canas A, Sharp A, Fuentes B. Hypothalamic-pituitary gonadal axis in boys with primary hypothyroidism and macroorchidism. J Ped. 1988;112(3):397-402.

40. Hoffman WH, Kovacs KT, Gala RR, Keel BA, Jarrell TS, Ellegood $\mathrm{JO}$, et al. Macroorchidism and testicular fibrosis associated with autoimmune thyroiditis. J Endocrinol Invest. 1991;14(7):609-16.

41. Suarez EA, d'Alva CB, Campbell A, Miller-Horn J, Dever M, Faerber $E$, et al. Absence of mutation in the follicle-stimulating hormone receptor gene in severe primary hypothyroidism associated with gonadal hyperstimulation. J Ped Endocrinol Metab. 2007;20:923-31.

42. Wortsman J, RosnerW, Dufau ML. Abnormal testicular function in men with primary hypothyroidism. Am J Med. 1987;82(2):207-12.

43. Jaya Kumar B, Khurana ML, Ammini AC, Karmarkar MG, Ahuja MM. Reproductive endocrine functions in men with primary hypothyroidism: effect of thyroxine replacement. Horm Res. 1990;34(5-6):215-8.

44. Donnelly $P$, White $C$. Testicular dysfunction in men with primary hypothyroidism; reversal of hypogonadotrophic hypogonadism with replacement thyroxine. Clin Endocrinol. 2000;52:197-201.

45. Rojdmark S, Berg A, Kallner G. Hypothalamic-pituitary-testicular axis in patients with hyperthyroidism. Horm Res. 1988;29(56):185-90.

46. Zahringer S, Tomova A, von Werder K, Brabant G, Kumanov $P$, Schopohl J. The influence of hyperthyroidism on the hypothalamic-pituitary-gonadal axis. Exp Clin Endocrinol Diab. 2000;108:282-9. 
47. Velazquez EM, Bellabarba Arata G. Effects of thyroid status on pituitary gonadotropin and testicular reserve in men. Arch Androl. 1997;38(1):85-92.

48. Kocova M, Netkov S, Sukarova-Angelovska E. Pituitary pseudotumor with unusual presentation reversed shortly after the introduction of thyroxine replacement therapy. J Ped Endocrinol Metab. 2001;14:1665-9.

49. Notsu K, Ito Y, Furuya H, Ohguni S, Kato Y. Incidence of hyperprolactinemia in patients with Hashimoto's thyroiditis. Endoc J. 1997;44(1):89-94.

50. Ridgway EC, Maloof F, Longcope C. Androgen and oestrogen dynamics in hyperthyroidism. J Endocrinol. 1982;95(1):105-15.

51. Nomura K, Suzuki H, Saji M, Horiba N, Ujihara M, Tsushima T, et al. High serum progesterone in hyperthyroid men with Graves' disease. J Clin Endocrinol Metab. 1988;66(1):230-2.

52. Abalovich M, Levalle $O$, Hermes $R$, Scaglia H, Aranda C, Zylbersztein $C$, et al. Hypothalamic-pituitary-testicular axis and seminal parameters in hyperthyroid males. Thyroid. 1999;9(9):857-63.

53. Krassas GE, Perros P. Thyroid disease and male reproductive function. J Endocrinol Invest. 2003;26:372-80.

54. Hanna CE, LaFranchi SH. Adolescent thyroid disorders. Adol Med. 2002;13:13-35.

55. Salerno M, Micillo M, Di Maio S, Capalbo D, Ferri P, Lettiero T, et al. Longitudinal growth, sexual maturation and final height in patients with congenital hypothyroidism detected by neonatal screening. Eur J Endocrinol. 2001;145(4):377-83.

56. Griboff SI. Semen analysis in mixedema. Fertil Steril. 1962;13:436-43.

57. De La Balze FA, Arrillaga F, Mancini RE, Janches M, Davidson OW, Gurtman Al. Male hypogonadism in hypothyroidism: a study of six cases. J Clin Endocrinol Metab. 1962;22:212-22.
58. Wagner MS, Wajner SM, Maia AL. Is there a role for thyroid hormone on spermatogenesis? Microsc Res Tech. 2009;72:796-808.

59. Corrales Hernandez JJ, Miralles Garcia JM, Garcia Diez LC. Primary hypothyroidism and human spermatogenesis. Arch Androl. 1990;25(1):21-7.

60. Trummer H, Ramschak-Schwarzer S, Haas J, Habermann H, Pummer K, Leb G. Thyroid hormones and thyroid antibodies in infertile males. Fertil Steril. 2001;76(2):254-7.

61. Poppe K, Glinoer D, Tournaye H, Maniewski U, Haentjens P, Velkeniers $B$. Is systematic screening for thyroid disorders indicated in subfertile men? Eur J Endocrinol. 2006;154(3):363-6.

62. Meeker JD, Godfrey-Bailey L, Hauser R. Relationships between serum hormone levels and semen quality among men from an infertility clinic. J Androl. 2007;28(3):397-406.

63. Clyde HR, Walsh PC, English RW. Elevated plasma testosterone and gonadotropin levels in infertile males with hyperthyroidism. Fert Steril. 1976;27(6):662-6.

64. Kidd GS, Glass AR, Vigersky RA. The hypothalamic-pituitarytesticular axis in thyrotoxicosis. J Clin Endocrinol Metab. 1979;48(5):798-802.

65. Hudson RW, Edwards AL. Testicular function in hyperthyroidism. J Androl. 1992;13(2):117-24.

66. Krassas GE, Pontikides N, Deligianni V, Miras K. A prospective controlled study of the impact of hyperthyroidism on reproductive function in males. J Clin Endocrinol Metab. 2002;87:3667-71.

67. Krassas GE, Tziomalos K, Papadopoulou F, Pontikides N, Perros P. Erectile dysfunction in patients with hyper- and hypothyroidism: how common and should we treat? J Clin Endocrinol Metab. 2008;93:1815-9. 